by I. I. GRANGE AND N. H. TAYLOR.

T'he object of this paper is to record a few observations on the peaty and peat soils of the Waipa County.

The -largest area of peat and peaty soils is that in the area known as Komakorau swamp which is about 13 miles long and about 8 miles broad. No detailed mapping has been attempted in this case but the writers have visited many localities on it of roughly equal area Moana Tua Tua and Ruhuhia swamps covering 18,000 and 17,000 acres respectively. Other swamps are those extending from Te Rapa west to $\mathrm{De}$ Kowhiai and that lying on both sides of the Thatawhata-Frankton Road. There are as well numerous small areas of 100 acres or so. The peats and peaty soils cover flattish areas which became badly drained during the time the Taikato and Waipa rivers were changing their courses in the Waikato lowlands. Contours made by the Lands and Survey Department show that in the case of Ruhuhia and Komakorau the old surface on which these organic deposits rest is not by any- mears flat. The old surface under Ruhuhia slopes to the North and under Komakorau to the North-west. Apparently then, at least, in these two casss, the whole of the area now covered with peat was.not swampy fellowing the blockage of drainage by the river sediments. Badly drained oonditions at the northern end of Ruhuhia and Komakorau allowed the peaty and peat soils to develop and the peat gradually extended southward owing to drainage conditions becoming progressively worse.

\title{
Classification.
}

The peaty and peat soils are divided into four main series, :-

1. KAIPAKI LOAMY PEAT, SANDYPEAT, PEATY LOAM AND PEATY SAND; $(33,000$ acres $)$.

2. TE RAPA PEATY SAND AND PEATY LOAM $(6,000$ acres $)$.

3. RUHUIIA PEAT $(52,000$ acres).

4. MOANA TUA TUA PEAT.

The soils of the Kaipaki and Te Rapa series occur on the margin of the big swamps and comprise the whole of the smaller swamps. Ruhuhia peat occupies the central portion of Komakorau, Ruhuhia and Whatawhata Road Swamps and a large part of the Moana Tua Tua swamp. Moana Tua Tua peat occurs in only one area - the central part of the swamp of that name.

(I) The Kaipaki series cover a a consicerable area in the Kalpakidistrict, along with the Te Rapa series forming a belt about one mile and a half wide bordering Ruhuhia peats. On the margin of Ruhuhia swamp, the belt of Kaipaki series is in general only about 20 chains wide except in the wide arm east of Ngahinepour 1 where the whole area is occapied by this series. $B u t$ probably the largest area of this series occurs in the margin of Komakorau swamp.

-The Kaipaki soils in many localities supported a forest vegetation, in which Kahikatea was abundant. The profile is:-

4-9 in. loamy peat, sandy peat, peaty loam or sand. on peaty loam or loamy peat.

The topsil to a depth of 9 inches or so, is, except in the Winter and Spring, dry and powdery, resembling s mewhat the struature of a fine sand. Those that are loamy show also a certain amount of crumb structure. The topsoil is usually a eark grey or dark brown. After repeated burnings it is a pinkish or cream sani 
or.silt 1 oam, The subsoil, brown in oolour has for a depth of a foot or so a nutty structure and is poor ly consolidated. Cracks which have 'opened' several inches are common, The total depth of peaty soil and subsoil lying on ordinary sands and clays is generalily not more than 3 feet.

(z)

The Te Rapa Soli, though peaty, is in reality a meadow soil. In the raipa County, it occurs chiefly in the Te Rapa and Kaipaki districts, lying between the Kaipaki soils and the higher flats running in narrow strips through the Kaipaki sois The largest area, however, occurs on the southern and eastern margin of Komakorau swamp, The vegetation on it was similar to that on the Kaipaki soils.

\section{The profile is:-}

9 ins dark grey peaty sand or peaty loam on buff to light brown sands or sandy loam.

The topsoil except in winter and spring is dry and powdery.. 'Its subsoil in most localities dries out in summer, but unlike the Kaipaki subsoil remains compact.

(3) Ruhuhia peat occurs chiefly in the central-portions of the big swamp. The vegetation is mainly manuka and rushes. A profile in the Ruhuhia swamp shows:-

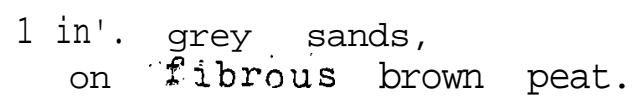

A field examination of the peat suggests that rushes and manka twigs are its principal constituents.

(4) ground water level on this type is almost a-t the surface.

\section{Moisture.}

The peatg soils do not behave like ordinary soils as regards their moisture, statue throughout the year, During the dry weather of last December, the peaty soils began to dry out, but judged by the pastures, not to the same extent as do the Hamilton clay loam and Hcrotui sandy loam. At the end of, the ciny spell - in early February, -. these soils were dry and powdery to about 12 ins, below the surface and the pastures fairly badly vilted, but, in mary cases, not so much as those in the Hamilton clay loam and Horotid sandy loam. Mith the rain in February, the soils became wet'only to an inch or so from the surface. This condition of the soil continued even ito the month of May. Late 'in June, the soils were becoming moist and the pastures showing their first ecided response of this year. Thus the peaty soils take a very long time to moisten and it is only in late rinter and Spring that they really contain a good supply of moisture,

A study of peaty soils leads to the conclusion that in them, as indeed on all soils, right moisture conditions are most important. Thepeaty lands in their natural state are saturated, with moisture, some of which must be removed before pastures can be established, If, h owe ver, they are drained dseply, the peat dries into a $p$ wdery or rubbly mass which will not readily take up moisture again. 'Throughout the Taikato are large areas of peat which may be described as slightly over-crained. On these are found a surface skin of 4-5 ins. of consolidated peat separated from the moist peat below by a layer of dry powdery or rubbly peat $12 \cdot 14$ ins, thick, The pasture shows the effects of this. Rye and clover remains ouly in the hollows and the Fog is stunted and spindly, That has happened is that drainage has proceeded faster than consolidation. The dry powdery layer would not have been formed had

(1) Consclidation been greater; or

(2) Had the drying out been slower, 
Enquiry needs to be made into the practical aspest: of controlling drainage on peat lands so that conso idation may keep pace with it.

The advisability- of sowing pastures on peaty soils in the spring should, also be considered, In Spring, the peats are warming and are slowly parting with their moisture.. In

Autumn, however, the soils arein the process of re-wetiting and are cooling down. In many localities, th ere seems better chano? of a pasture being successfully established in sprirg than in the Autumn, though it must be said that there are some difficuities: notably the growth of sorrel.

Pastures.

The pastures cn the pety soils are genera? iy poer when compared with those growling on the other soils of the coungy, They show a fairly olose relation to the percentage of minera! matter in the soil, the better pastures being found on the Te repa. and Kaipaki peaty loams. Poorer pastures. are found or the Kaipais loamy peats and still poorer ones on the Ruhuh'ia. peats. To obtain some exact data on the pastures, field analyses were made -25 point and 43 estimated analyses. Most of the pastures on Te Rapa soils contain only a low proportion of rye-grass. and all examined are low in whito clover, Paspalum, Yorkshire Fog and Brown top form a' large proportion of the sward on most fields. During tine dry summer spell the clover content"was very low, and there was little sign of its recovery, with the autumn rains. The main Increase in autumn growth on many of the pastures was in the fog and brown top. Farmers state that the pastures do not quickly show the sighs of dry weather, but once they are affected they are s.ow to recover.

The pastures of the Kaipaki soils. resemble those Of. the Te Rapa series; but they vary greatly with the actual son. If e and with field conditiors - notably diranage. Some good long established pastures of rye and white clover and paspalum are to be seen 'on the Kajpaki p eaty loams but on the l oamy p eat :

although. good rye-elover pastures can be sown down. few last

longer than two"years under present methods of treatment.. Afte: a few years cn most fields the rye and clover disappears from 0.1 but the lowest hollows, the fog becomes tufted and spindly and brown' top takes charge. The average composition of some atw.t good pastures in this type is shown on Table 1 . Table 11 sinows the seasonal change in pasture composition on a fairly good field situated on Kaipaki loamy peat. This is typical of the change that goes on in the Kaipaki and Te Rapa peaty soils. Clover is reducoe very much in the dry weather and when the rains come in February the bare spaces are filled up with weeds.

\section{T A B L E 1 .}

AVERAGE OF 7 POINT ANALYSES-OF FAIRLY GOOD PASTURES ONA-C, KAPAKI

RYE GRASS

PASPALUM

YORKSHIRE FOG

BROWN TOP

SWEET VERNAL

YHTTE CLOVER

LOTUS MAJOR ETC.

WEENS

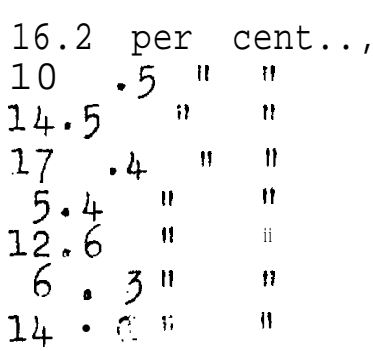




\section{5th DECEMBER:}

16 per cent
22
10
24

\section{3th FEBRUARY;}

27th APRIL.

RYE GRASS

FOG

WHITE CLOVER

WEEDS

23
1
56

17
22
5
39

All observations on the peaty soils gn to show that clover suffers much more than the grasses when there is a shortage of moisture in the soil. It was noticed also that on the dry hummocks; the clover, besides making up only a small percentage ci the pasture, has small leaves, whereas that on similar soil in the damp hollows forms a greater percentage of the pasture and has much bigger leaves.

\section{Plant Food.}

The Kaipaki and Te Rapa Soils are well supplied with available phosphoric acid, the amounts being unusually well above thinse in the mineral. soils which have had similar manuring. I $n$ the ease of a Kaipaki soil at Ohaupo nanured with 4 cwt. of super for several years, the figure is outstandingly high $0.133+$. A pinkish ash which had very little top-dressing has 0.072 per cent. The lowest figure obtained was $0.026^{\circ}$ per cent on a paddock put into pasture 8 years ago and topdressed each year with 2 cwt. of super.

Eren in this soil the phosphate is perhaps not on the low side. This evidence suggests that high phosphate dressings are not required on the Kaipaki and Te Rapa soils but the actual position can only be determined by field trials. The peaty soils are not markedly acid; they are in general somewhat more acid than the mineral soils, but the $\mathrm{pH}$ is in some instances above that of individual minerel soils.

Need fof further research.

Peats and peaty soils occupy somewhat less than half of the Waikato lowland, large areas lying close to the towns and the railways. After several attempts to farm therm, many areas of the soils have been abdndoned. Other areas are stillbeing farmed 'but, on the whole, 'the results are unsatisfactory. Further attempts to develop the peats are'continually being made and much money and human effort is thus spent. This primitive and uneconomic way of gaining knowledge should be replaced by organised enquiry which could speedily add much to our knowledge, re'garding the control of the moisture and the methods of fertilising on these soils. Sufficient evidence has been given t: show the importance of these questions.

The the possibilities and limitations of the various peaty soils definitely known, great benefit would be conferred on the Waikato district. 